\title{
Home Video Films and Grassroots' Relevance in Nigerian Political Process
}

\author{
${ }^{1}$ Alawode, Sunday Olayinka (Ph.D), ${ }^{2}$ Sunday, Uduakobong \\ ${ }^{1,2}$ AdebolaAdegunwaSchool of Communication, Lagos State University, 21 Olufemi Street, Off Nathan St, \\ Surulere - Lagos
}

\begin{abstract}
The Nigerian home video films have been used to address a myriad of existing and emergent problems because of its distinctiveness and popularity; as a popular art in Nigeria, this study was undertaken to investigate the consideration of the grassroots in the Nigerian political process from the eye of the home videos. The theoretical framework employed was agenda setting with content analysis as the method of research. The results reveal that the grassroots are not given credence as a key factor in the films except as means to justify the ends of the political class and players in the political process. The roles of the grassroots in the political arena are mostly depicted significantly as thugs, assassins, villains, prostitutes and others who are involved in different kinds of undesirable practices and vicious acts. Such portrayals could be contributory to politics often being described as 'a dirty game' with the grassroots increasingly having apathy to political processes and creating the divide of 'them' and 'us'; where 'them 'is the political class and 'us' being the grassroots.
\end{abstract}

Key Words: Grassroots, Home Video, Political Process

\section{Introduction}

The home video is a narrowcast medium through which a desired audience can be reached by means of television and drama (acting); it is a thriving medium (undertaken by the Nigerian film industry popularly called (Nollywood) which seem to be overtaking celluloid through its offerings (ibid).The home video has become a popular information and entertainment medium all over the world (Alawode, 2010). Popular opinion based on UNESCO (2007) report holds that the Nigerian film industry, which is dominated by home videos is currently rated second in production of films after Bollywood (India) and over Hollywood (America). By implication, Nigerian films (home videos) are widely watched. The home video is a medium of communication which many individuals, people and organizations can utilize for different purposes, advantages and disadvantages (Alawode \& Sunday (2013). The films are produced in different languages including English and Yoruba - sometimes subtitled in English (which seems to rank as high as the English productions in terms of volume) and into the market. The home video phenomenon in Nigeria is widely accepted because of its indigenous contents and ability to address issues relevant to a mass audience. Through the amalgam of Nigerian (African storylines) and western technology, the films depict and recreate socio- political and cultural events that occur within and beyond the country's borders. The prices of the films range from 100 Naira to 400 Naira (less than $\$ 1.00$ to about \$2.50) depending on the age of the film. This is affordable to most people including children and the notso- rich. Being affordable to all and sundry in the Nigerian society, its offerings should expectedly reach and meet the needs of every person as well as answer salient questions as they provide information to enable the populace take political decisions as they get involved in the political processes.

\section{The Problem}

According to Jorum (2003), the media can be defined as including all aspects of the transmission of cultural, social and political values. Mass communication include: radio and television, which home video is identified with. Most people are not closely involved with politics so communication of ideas and information has to be taken by other means; the media is essential for effective function of society. Nwosu (1991:94) on his part adds that all the functions of any political system such as - Nigeria's political socialization and recruitment, interest articulation, interest aggregation, rulemaking, rule application and rule adjudication - are performed by means of communications. He further asserts that the mass media have been found to be especially useful in performing the political socialization and mobilization functions in Nigeria and other countries. Prior to the prominence of widespread television (media) coverage of political processes and activities in Nigeria, only the elites, the enlightened and the sophisticated were privileged to have diverse media exposure through which they obtained information, especially on political issues and subsequently relayed same to others. Political information was not as widespread as in today's age of technology; wherever people are on the face of the earth, they can be effectively informed on every kind of issue as they may desire. Knowledge of political processes and activities are no longer restrictive to any particular group of people due to barrier in communication. The 
mass media transmits programmes in English and indigenous language alike. This dispensation is also considered as the age of 'infortainment'. Through the means of entertainment devices, information can be relayed (McQuail, 2010:560). According to Ghosh (2010), information and entertainment are key ingredients of human development. Mainstream mass media alone with their primarily market-driven content and top-down dissemination mode are unable to gratify the needs of the masses at the local communities. Drama, films and movies which can be combined to define the home video are means through which people obtain information while also being entertained.

Data from Alawode's (2010) study on Uses and Influences of Nigerian Home Video among Audience in Oyo State, Nigeria reveal that the users of the home videos indicated the home entertainment, information and education as the three most important reasons for home video use. It is understood that the urban, semi -urban and rural dwellers have almost equal access to home video as indicated in the table below:

Table 1: Chi-square showing Location and Access to Home Video

\begin{tabular}{|c|c|c|c|c|c|c|c|}
\hline Location & No & Yes & Total & $\mathrm{x}^{2}$ & Df & sig. & Rule \\
\hline Urban & $\begin{array}{l}53 \\
(11.8)\end{array}$ & $\begin{array}{l}97 \\
(21.6)\end{array}$ & $150(33.4)$ & & & $* .001$ & Significant \\
\hline Semi-urban & $\begin{array}{l}29 \\
(6.4)\end{array}$ & $\begin{array}{l}123 \\
(27.3)\end{array}$ & $152(33.7)$ & 15.162 & 2 & & \\
\hline Rural & $\begin{array}{l}27 \\
(6)\end{array}$ & $\begin{array}{l}121 \\
(26.9)\end{array}$ & $148(32.9)$ & & & & \\
\hline Total & $109(24.2)$ & $341(75.8)$ & $450(100)$ & & & & \\
\hline
\end{tabular}

Source: Alawode (2010:139) *Significant at $\mathrm{P}<0.05$

This is represented by $27.3 \%, 26.9 \%$ and $21.6 \%$ of the respondents for the respective categories. Home video films are therefore within the reach of almost every Nigerian citizen. Following findings from focus group discussion on the study, benefits of home video offerings include gaining political knowledge, business acumen, and trade, passing information to society, family unity, family continuity and source or mirror for way of life.

The mass media have made undisputable impacts in the modern political scene .It provides us with information almost instantaneously and sets the stage for leaders to take quick action affecting the scope of government. The home video on its part has been acknowledged as a popular information and entertainment medium all over the world hence this study seeks to find out if the grassroots people are justifiably represented in the home video? How are they represented and how relevant are they in the nation's political process? This can be justified through their depictions in the home videos, the symbols, totems, items and the story lines/themes .According to Sabine and Thorson (1973):

The institutions in a society that we would be likely to designate political represent an arrangement of power and authority ... when the interested groups or individuals take actions directed towards the political institutions, such actions become part of political nature. This can be physical or primarily verbal or combination of the two

While politics is seemingly an elitist affair, every citizen (of voting age) in every country is expected to participate in political process, if the country must be effectively developed. Citizens of countries must vie for political positions (offices) and citizens must cast votes to elect people into political offices. Electoral positions are not restrictive to the urban areas; rural communities are also represented in the political processes. Electoral positions are also not limited to the very rich nor influential; persons eligible by virtue of age, stipulated conditions and status can vie and equally vote and be voted for. Political processes transcend democratic affairs to traditional affairs in every community. Just like presidents, governors and local government chairmen (officials) are elected, kings, chiefs and other title holders are chosen to run the affairs of every community. Members of the grassroots are expected to be involved in all of the processes. The candidates are representations of people from various states, local government areas, wards and villages in the country; hence people that make up the grassroots cannot be excluded from any political process; neither the president nor governor of any country/state can be elected without the involvement and support of the constituents of the grassroots; not a king nor the traditional title leaders nor title holders in any community may also be selected without inputs from the ordinary people in the community. The ordinary people in the local communities would be considered disenfranchised or cut off from the affairs of such a community if they do not have representations in positions of authorities. This is one of the reasons for undertaking this study to see how grassroots representation and participation is projected in the Nigerian home video, a veritable and accessible means of communication within the reach of the populace.

According to Okadigbo (2010), the essence of the grassroots politics is to promote political leadership and dividend of democracy for the electorate. This is because in a democracy, power emanates from the people and as John Locke, the English political thinker said "power is a trust which the leader holds on behalf of the electorate". Grassroots politics is the surest way of making the elected leaders listen to the needs, aspirations and problems of the people and take political steps to meeting those needs. In our modern time, grassroots politics 
has become a major and popular yardstick for measuring the success or otherwise of elected political leaders. Indeed, following the principle of sustainable development which United Nations Development Programmes (UNDP) advocates through implementation of bottom - top development projects, grassroots participation and representation in politics would be the proof of affective democracy.

\section{The Grassroots and Political Process}

\section{Literature}

Ghosh (2010) posits that the participation of grassroots in the political process entails the proactive role of media. The mainstream mass media with their market-driven content and diverse audience are inadequate for grassroots empowerment. The participatory community media allow the grassroots to be involved in the management and in the content production process. In the paper which he explores the potential of community radio as a participatory media in Panchayat areas of West Bengal and its effectiveness in attaining political empowerment for the Panchayat members, Ghosh asserts that political empowerment has eluded the grassroots because of the influence of external factors; also the presence of a community radio would have mobilized grassroots participation in political process. He further suggests that the mass media direct approach, rare interaction and insignificant feedback were not ideal for grassroots empowerment hence the necessity to derive alternative participatory media. It is this alternative participatory media that has prompted the consideration of the home video films in Nigeria as a mass medium to reach the grassroots as well as one that would give expression to grassroots relevance in Nigeria political process.

According to Simbulan (2010), grassroots is the foundation for any successful advocacy initiative. It is the number one reason why legislators vote for or against pending or proposed bills. It gives leaders (policy makers) opportunity to help make their contributions in governance. Bisi Akande as reported in Vanguard newspaper (Akinreron, 2012) posits that because the masses live in the grassroots makes it imperative to focus more attention on issues evolving from it. He believes that issues concerning grassroots politics should be given serious consideration in relation to governance and economy of the nation. According to Forsyth $(2012$, the reality is that while studies and testimony can be powerful tools in persuading law makers to support a piece of legislation, messages and visits from the 'folks back home' (especially when they represent a large number of potential voters) are what catch the attention of the member and his/her staff. The bottom line is that grassroots activity is critical to sustaining support and gaining a champion - someone who will choose your issue as one of his/her top priorities. In Bakers' (2010) opinion, a traditional grassroots movement is a movement started by a concerned group of individuals to promote an idea or cause. Such activities are not limited to influencing legislators; media outlets are now often target of those types of informational campaigns. The campaigns may include organizing voters' registration drives, hosting house meetings, putting up posters, even knocking on doors as well as all other traditional activities. In recent years, many organizations, companies and associations have format grassroots programmes, designed to encourage direct participation in political process but many have questioned if that is in fact 'true' grassroots.

Jacobs (2002) referring to Linz and Stepan (1996:31), suggests that while increasing political participation at grassroots is only part of the process of generating democratic accountability, such involvement and willingness to take part in the political system may provide a foundation for expanding democratic engagement. Local and national participation focuses not only on changing government responses but also on changing society and the community, creating local alternatives to traditional politics and links to international networks. The types of behavior that links the grassroots with state, national and global organization fits into a pattern of what some describe as world civil politics that "define and shape public affairs at all levels. White (2009) explains political culture to include broad assumptions about legitimate ideology, norms of political participation, and the structure of representation in the society.

According to Shapiro and Winters (2008), political participation in democracy can take many forms ranging from voting for representatives at regular intervals to voting on policies in referenda, forming political groups and engaging in legal and illegal protests. The individuals engaged in such participation would likely expect - or at least hope that those actions will have some impacts on the content of government policies. The effect of the political participation might also affect individual life satisfaction and happiness. In the aggregate, political participation could likely have important effects on policy choices and outcomes. Political participation may provide individuals with direct utility and thereby increase happiness and satisfaction with life in general. Referring to Drene and Sen (2002:359), they further explain that participation can also seem to have intrinsic value for the quality of life: being able to do something through political action for oneself or for others - is one of the elementary freedoms that people have reasons to value.

Simbulan (2010) further asserts that hope is not in electoral struggle per se; the real hope lies in democratization to strengthen and widen grassroots citizens: links and unity and struggle with various interest and professional groups, not just class-based political movements should be established and firmed up, the grassroots participation should be encouraged in political processes. The role of the grassroots is not just to 
check and balance in the state or to share power. This would be tantamount to cooptation and may result in the divided grassroots movement.

Luan (2001) puts succinctly that the main approach of grassroots democracy is "let people know, people discuss and people supervise: the activities of local government in order to mobilize active participation of people in social, economic and political processes at grassroots level and to change the working style of the local government thereby reinforce the political system and make it more effective.

\section{The Nigerian Home Videos}

Akeh posits that the era of foreign films in Nigerian homes has gone, and now is the time that Nigerian situation as presented by Nigerian actors and actresses are seen not only in Nigerian homes but all over Africa and the rest of the world. He celebrates the fact that indigenous Nigerian film makers have evolved the video film culture as an affordable means of (re) presenting the Nigerian nation to silver screen. Ekwuazi (2003) explained at a national film festival that home video in Nigeria is worth celebrating as an emergent art, as a veritable and accessible means of communication as well as a burgeoning industry. Haynes (2005) puts succinctly:

Nigerian video film is ... what is on television in Namibia, and on sale on the streets of Kenya.

In Congo, they are broadcast ... In New York, Chinese people are buying them. In Holland,

Nollywood stars are recognized on the street by people from surname and in London, they are

hailed by Jamaicans.

Ebowo (2011) affirms that home videos are popular in Nigeria because they have indigenous contents and address issues relevant to a mass audience. Since early 1990s, the home video industry now stylishly called 'Nollywood' has churned out thousands of titles and brought many producers, marketers, actors and technicians into limelight. The 'home video' is a household expression in contemporary Nigeria and has become a popular form of audio-visual entertainment. The industry has also become too significant for the world to ignore. Uwah (2008) explains that Nollywood (the Nigerian home video industry) has significantly become involved in the process of African's self-reflection and identity construction by means of its culture representation. Even though, this may not be the primary objective of this work, it cannot be ignored in the subject of Nigerian home videos films. The cultural symbols and identity would be identified, especially in the traditional political settings.

\section{Theoretical Perspective}

This study is hinged on agenda setting theory to identify the agenda set by the producers of home video films as they represent the grassroots and their relevance in the Nigerian home videos. The reviewer in The University of Twente (2012) describes agenda setting as a very powerful influence of the media which is the ability to tell us what issues are important. The two core assumptions that underline most researches in agenda setting are:

(i) The press and media do not reflect reality; they filter and shape it.

(ii) Media concentration of a few issues and subjects lead the public to perceive those issues as more important than other issues.

One critical aspect in the concept of agenda setting role of mass communication is time frame for the phenomenon; different media have different agenda potentials. As far back as 1922, the newspaper columnist, Walter Lippman was concerned that the media had power to present images to the public. McCombs and Shaw investigated campaigns in 1968, 1972 and 1976 through which they established this theory. In their research done in 1968 on Presidential Campaigns, they focused on two elements: awareness and information. Towards investigating the agenda setting function of the mass media, they attempted to assess the relationship between what the voters in one community said were important issues and the actual content of the media messages used during the campaign. McCombs and Shaw concluded that the mass media exerted a significant influence on what voters considered to be major issues of the campaign.

According to Cohen (1963), the press may not be successful much of the time in telling people what to think; but it is stunningly successful in telling its audience what to think about.

The favourite method used in determining agenda setting potentials of any medium is usually content analysis of the chosen medium (as well as interview of audience). The agenda setting theory seems quite appropriate to help in establishing the pervasive role of the media, for example on political communication system. 


\section{Method of Research}

Content analysis was employed for the study to determine the representations and portrayals of grassroots participation in political processes as well as different kinds of political symbols and identifications in the films analyzed. The videos studied were exclusively Yoruba and English home videos from the stable of Nigerian film producers under the auspices of the Nigerian film industry (Nollywood) and approved by Nigerian Film and Video Censor Board (NFVCB). Yoruba home video films were 76\% [twenty -five (25) films] while English productions were 24\% [eight (8)].

Thirty three (33) home video films were carefully selected and watched; twenty-five (25) of the films were borrowed from video club, two (2) were watched as programmes on television stations - NTA 2 Channel 5 and TVC respectively and six (6) was watched from YouTube. All the borrowed films had production in many parts - ranging from two (2) to four (4). For the Yoruba films - in cases where the titles had productions up to three or four parts, only parts one (1) and two (2) were watched; while only part one was watched out of titles that had part one (1) and two (2). The entire films were watched from the home videos shown as television programmes on NTA2 Channel 5 and TVC and the first six clips were watched from YouTube clips. For the English productions, all the parts were watched.

Coding Categories were developed from variables as individuals/people, socio-economic status, place/setting and location of participation, purpose of participation, machinery of mobilization, attitudes of the grassroots to political process, attitudes of politicians and political symbols/totem/items. This provided guide to identify their representations in the video films. Data were analyzed qualitatively; only portrayals and representations relevant for the purpose of this work were identified and analyzed.

\section{Results And Discussion}

The home video has been used to inform, educate, tell stories, and explain issues and situations as well as criticize situations, circumstances and people. Through the home video people have learnt how to handle situations/issues and how not to handle same; people have learnt how to conduct themselves as well as how not to. The home video has also been used to abuse and disabuse people's minds and situations/circumstances. Through the agenda set by the home video makers in the production of English and Yoruba films with political contents considering the films studied, the results are presented thus:

The grassroots people identified in the films were predominantly: thugs, hired assassins, prostitutes, and girlfriends to politicians, gate keepers and house maids, native doctors, palace attendants (maids and guards), security attachés, farmers, journalists, film makers and people with no definite identity but members of the communities amongst others. The grassroots people are rarely given significant roles in the political process. Most of the films in both traditional and civil political scenes in the home videos did not show the grassroots involvement in political process as a major factor; emphasis is often given to the power brokers and their contenders. There are however certain indicators of the grassroots in certain perspectives.

The Yoruba home video film Opomulero (2009) significantly highlights active grassroots participation in the Nigerian political process. It also showcases greater number of activities in the political processes than most other films. The activities include: declaration of intention by political aspirants, attitudes of both honest and dishonest politicians and the desperate dishonest politicians like the man, Babalola, whose ambition to hold a political power either 'by ease or by force' causes him to employ thugs to eliminate his opponents like Mr. Olododo and Mr. Thomas. He sponsors acts of hooliganism and incessant disturbances in the community where the people are molested to silence. Notwithstanding the threats to life, the people in the community refuse to be intimidated. We see them in groups discussing the unhealthy political situation in their community yet with increased resolve to vote for credible candidates. Like all the other films on civil politics (both English and Yoruba productions) including Corridors of Power(2010)EkuMeji (2011), Arole Aare (2012), Ota Koko (2012), Arufin (2010), Opomulero reveals incessant acts of hooliganism, insecurity, assassination and stage-managed riots sponsored by desperate politicians. Agents of politicians are also projected as they go about tearing opponents' posters. Grassroots participation in political activities is also seen through their involvement in rallies, and youth meetings for awareness and enlightenment. Through films like -Baba Gomina (2010), Arole Aare (2012), Owo Okuta (2009), Government House (2004), Government Babes (2012) and Girls Cot (2012), the audience is informed of how associates to political office holders can exercise excessive unconstitutional power with or without the supports of the office holders. The Governor's father in Baba Gomina uses his privileged status to exploit the house members to create financial votes for him hence loots the national treasury to the embarrassment of his son, The Governor (Yomi Fash);most of the times, his son would be ignorant of his father's schemes and activities. In Arole Aare, the wife of the Governor engages official security men to kidnap and assassinate citizens who are privy to her well-kept secret. In Owo Okuta, the son of a former Governor asks his father to allow him use the official jet and power bike on trips and to move about. In Government House, the Governor's sister holds the office of 'First Sister' and seems to be the person who controls the affairs of the state including the Governor's wife. Upon her brother becoming the Governor of the state she arrives from United 
States of America to have her national cake as 'The First House'. In both Government Babes and Girls Cot, female associates of political office holders like children of The President, Vice President, Inspector General of Police are shown molesting and terrorizing people as well as flaunting wealth derived from their political connection. In Political Babes, an illegitimate daughter of the Vice President penetrates the security machinery and obtains security documents which she would use to blackmail the senators, ministers as well as her father to obtain rare favours. In Ife $M i$ (2011), a film producer is employed by a politician to produce films 'to educate the electorate and to create awareness on his projects which should correct injustices in the society'. The film producer is expected to promote (praise worship) the politician in the film. His partner, who is a journalist is not comfortable with the (brown envelop) gratification given to her by the politician; so she rejects it. The politician undertakes campaign from ward to ward through the women leader of their party: to mobilise and distribute money to the old women. In Arufin (1999), Saworoide (1999) and AgogoEewo (1999), the grassroots people are employed to carry out rallies/carnival to promote politicians. Arole Aare reveals how the security personnel attached to top officials in governments suffer on account of their bosses. The Chief Security Officer's (CSO) mother is kidnapped and later killed (with further threat to kill every member of the family) as a means of getting her son to cooperate with the people who have been blackmailing the Governor. In the traditional political scene, spiritualists, native doctors and priests play very significant roles in the political processes. In Cat in The Palace (2012), the king's uncle, desirous to become the king after the death of his brother who was killed by him through fetish means gives a beaded necklace to a palace maid, Uloma, which turns her into a cat (witch) without her knowledge. Through such, a lot of havoc is caused in the palace including frequent abortion of the queen's pregnancies. In almost all the cases, Ifa is consulted to choose successors to the thrones upon the death of the reigning kings. The Ifa priest would always determine the process to follow, the requirements and expectations of the king-elect, for example in Ite Oba (2011), Saworoide andAgogo Eewo and Ori Olorun(2011). The Ifa priest is usually very powerful that even the king-elect and reigning king would take directives from him; no one contravenes any. Whenever there is a challenge or crisis in any community, the Ifa priest's opinions are not usually disregarded. This is however not so in Saworoide where the king refuses to comply with all the demands for his coronation. He tells the priest that he is the king and decides on what to do and what not to do. Desperate for her son (who had been foretold would be a king in an undefined future) to become a king in her lifetime, a woman in Ori Olorun seeks help through a native doctor to cause the reigning king to die; the native doctor consults with witches and wizards, Ifa, Sango and Esu. Mysterious things happen in the community leading to the death of the reigning king. The woman's son, Akinlabi is taken through the coronation rituals by the Ifa priest where he falls and dies in the shrine before being crowned. In Isinku Asoboji (2009) the role of occultists in solving challenging situations in the community is very pronounced. Following the death of Reverend John Adeyemi, who was an occult member; members of the fraternity go to his grave to get their 'due' as was determined by him, only to discover that his eyes, ears and tongue had been removed. They report to the king and receive mandate to find the perpetrator(s). The occult members then invoke spirit of the dead man and command him to locate whoever tampered with his body parts and deal with same. Not long after, the king's mother dies and is buried. The audience sees her crying at night and making demand for her eyes, ears and hands to be returned. The occult members again summon her spirit as in the former case. The culprit, who is a prominent chief in the community, dies mysteriously but his coffin refuses to go into the grave. The occult members also summon his spirit and discovered that though he was a philanthropist, his source of wealth was through rituals undertaken with dead people's body taken from the graves in the community. His coffin is forthwith burnt with his body by the occult members. In Sawororide, the people of Jogbo take up arms and undertake a protest against the reigning king who is insensitive to their plights; they also plan to capture and lynch him. The people of communities in the films - Ori Olorun and Alaafin Aoole (2011) give clothes, palm wine, yams, fruits and different kinds of farm produce as gifts to the king. In Alaafin Aoole, the king forcefully dispossesses his subjects of their property and their wives.

The grassroots people representatives in the home videos seem to be projected as objects to be used to achieve the politicians' ends, to the negative advantage of the politicians against the effective development of democratic processes. They are engaged to undertake vicious acts of hooliganism, assassination and all manners of unhealthy acts in films like -Ife Mi, Arufin,OwoOkuta, EkuMeji, Saworoide,AgogoEewoand Corridors of Power. In Arufin, a housemaid of a politician (Seyi) who was lured into sexual relationship with him with a promise to make her life better becomes pregnant; then he sends his thugs to kill her. Seyi is saved by an acclaimed assassin who trains her to be tough and become a member of their gang. Seyi subsequently undertakes to recruit other ladies from the university into her gang. All the home video films (for example AkobiGomina) showing civil political process would usually have or suggest politicians having sexual relations with girlfriends and/or prostitutes: some of whom would be sponsored on oversea trips. In Government House, the Governor would often ask his girlfriend, whom he made to live in his personal guest house abort pregnancies he was responsible. The lady loses her womb eventually. In Ayo Olamiposi (2009), the Chairman of a Local Government Area is robbed by a group of youths amongst whom are his son and a lady. In Ite Oba(2011), in 
order to be made a king, a contender to the throne takes some organs from a lady who has been his sexual partner. The lady then after suffers from a sickness which defies cure. In Corridors of Power, the police officer attached to the Minister of Finance, a key power broker is engaged by aggrieved politicians to kill him. His personal secretary, without his knowledge, also doubles as an agent to those who seek his destruction. In Sarowoide, the grassroots people can be lauded for making some relevant inputs to political processes; their voices are heard as they react to the prevailing political system. The farmers and hunters representatives are seen amongst the others as they go to meet the king to discuss their plights. The masses take up arms against the king who has no interest in the progress of the people or their welfare.

\section{Discussion}

In a budding democracy like Nigeria which operates with increased political apathy resulting from general attitude of distrust of the political class by the grassroots, portrayals in the home videos should be intended to educate, inform and create awareness about the political processes and expectations from the electorate. By this, the producers of the home videos should have created scenes where the grassroots are mobilized towards effective involvement in the democratic processes; scenes where they are given awareness of political processes should serve to educate and dissuade them from distrust, abuse and subsequent apathy. Such scenes would also serve to provide the right knowledge, information and thinking against hitherto mistrust which the grassroots are usually fed with. Where such information is not corrected through the home video portrayals which are watched by both the literates and illiterates, the rich and the poor, the elites and the grassroots, the people at the grassroots who would understand the portrayals in the home videos as representations of reality and therefore they expectedly would understand the political terrain as being dangerous, having little or no place for the grassroots thus the divide of the 'them' and 'us' would remain: where 'them' are members of the political class who are seen as relevant in the political processes and would eliminate whoever opposes their viewpoints and who only use the grassroots people to their negative advantage; and 'us' is the grassroots people who are the silent majority, irrelevant and voiceless people who only exist to be used and destroyed by the elites and the political class.

Through the political processes, the researchers had expected to see situations in the home videos where grassroots people would progress from onlookers' status to being leaders, from being represented to being representatives, from being grassroots into the political class. Unfortunately, none of the films studied revealed any of such progression. There should have been settings where the masses would meet to decide who would represent them. Contrary to the thinking of the researchers that political representation is implicit in political participation and political processes, portrayals in the Yoruba home videos studied reveal otherwise with respect to participation of the grassroots. The grassroots members of the society are not portrayed with significant representative capacity in any of the films studied. Film makers should have ensured that concentration of grassroots people are not only expressed in the negative light as objects to be used or employed for destructive purposes, in vicious acts as villains, hooligans, thugs, assassins and prostitutes. They can be shown in the films discussing why a particular candidate should be voted for or not; they can be shown casting votes in the voting booths. Scenes of the masses showing anxiety over the election of their candidates should also be included. While it may be necessary to reveal the negative tendencies in the political terrain, it is important to highlight definite positive aspects of politics and its processes to enable the populace understand the right things to do.

\section{Conclusion}

The media should serve as the watch dog of democracy and should perform the task of protecting the people's interests. Through its offerings, the media should play a pivotal role in enabling the people to be aware of political happenings, their rights, and actions of the political class as well as expectations from the grassroots. The home video as a medium of communication can be in the frontline of the battle to maintain and sustain the country's budding democracy and its ideals. The home video films should be seen as the eyes, ears and voice of the people as they are recognized as representations and representatives of the people through balanced portrayals. sThe audience of the home video films should be educated and informed while also enjoying entertainment. The Nigerian government through its agencies handling political communication, political awareness, political mobilization and political socialization should not be left out in the provision of contents for the home video film productions; collaboration would be helpful to enhance the film productions.

\section{References}

[1] Akinreron, Dapo (2012), 'Grassroots development panacea to good governance' www.vaguardngr.com/2012/grassroots_developmen_panacea_good_governance_akande

[2] Alawode, S. O and Sunday, Uduakobong (2013), 'Home Video as Nigerian Image Maker' European Scientific Journal April 2013 edition vol.9, No.11 
[3] Alawode, S. O (2007), 'Nigerian Environment in the Eye of Nigerian Home Videos,' Journal of Communication and Language Arts, University of Ibadan

[4] Baker, Melinda (2010), Grassroots, grasstops and ...Astroturf, Vol 95, No 6, Bulletin of American College of Surgeon

[5] Bell Judith, 'Doing your research project' in Spark, G. (ed) (2006) Media effects Research: A Basic Overview, United Kingdom: Thomson Wadsworth

[6] Ebowo, P.J. (2011) The Nigerian Video Film Industry: Challenges and Prospects, http://ugowrite.blogspot.com/2011/01/Nigeria video film industry

[7] Forsyth, S. L. (2012) 'Grassroots... What's the Big Deal', American Psychological Association, Washington D.C

[8] Ghosh, Jhumur (2010), Community Radio: its Prospect and Role as A Participatory Communication Media in West Bengal Panchayat, India: Calcutta University, West Bengal

[9] Haynes, J. (2005), 'Nollywood: What is in a name?' nollywood.net Nigeria \& African film makers, July 2004

[10] Jorum, Dpace (2010), The Mass Media and Political Communication, United Kingdom: Bitstream publishers

[11] Jacobs, Jamie (2002), "Community Participation, The Environment and Democracy: Brazil in Comparative Perspective", Latin American Politics and Society, Vol 44, No 4, pp59-88

[12] L'uan, Trinh (2001), How can the implementation of Grassroots democracy Help the Poverty reduction Strategy in Vietnam, Vancouver: National Centre for Social Science and Humanities, Institute of Sociology

[13] Mass Communication Theory: Agenda Setting (2012), University of Twente Review McQuail, Denis (2010), McQuail's Mass Communication Theory, London: Sage Publications Ltd

[14] Nwosu,Ikechukwu(1991), "The Communicative Import of film in National Development" in Okadigbo, Innocent 'Nigeria: Political Leaders, Grassroots and Politics' in Adamolekun, Wole (2010, September 12), Social Mobilization: Tool for Effective Grassroots Communication for National Transformation, All Africa

[15] Sabine, G.H. and Thorson, T.L. (1973),A history of Political Theory, Holt- Saunders International Editions, Canada: The Dryden Press

[16] Simbulan, Roland (2010), Grassroots Movement and Electoral Politics, Inquirer.Net, Philippine News for Filipinos

[17] Shapiro, Rebecca and Winters, Mathew (2008) Political participation and Quality of life, Columbia University

[18] United Nations Report, 2010

[19] Unoh, Solomon (ed) (1991), Tropical Issues in Communication Arts, Uyo: Modern Business Press

[20] Uwah, Innocent (2008), Religion, Media and Politics, Port-Harcourt, Nigeria: Catholic Institute of West Africa

[21] White, Deena (2009), Network, Governance and Democracy: Can Grassroots Participation Influence National Policy Orientation, Department of Sociologie, Universite de Montreal, (paper presented at Annual meeting of RC19 of the Internal Sociological Association Montreal, august 20-22, 2009

[22] Alawode, S. O.. (2010) Uses and Influences of Nigerian Home Video among Audience in Oyo State, Nigeria, Ph. D thesis University of Ibadan 